\section{Peter de Rivo}

Serena Masolini ${ }^{1}$ and Christopher Schabel ${ }^{2}$

${ }^{1}$ Institute of Philosophy, KU Leuven, Leuven,

Belgium

${ }^{2}$ Department of History and Archaeology,

University of Cyprus, Nicosia, Cyprus

\section{Abstract}

Peter de Rivo (c. 1420-1499) was a controversial scholar active at the early University of Louvain. He was professor of philosophy and rhetoric in the Faculty of Arts, professor of theology, and served three times as rector of the university. He was a canon of Mechelen and plebanus of Saint Peter in Louvain. He wrote a series of commentaries on Aristotle, a Gospel Harmony, and treatises on the dating of Easter and calendar reform, some of which stemming from a quarrel with Paul of Middelburg. He is best known as the leading protagonist in the so-called Quarrel over future contingents against the Louvain theologian Henry of Zomeren. The dispute between the two goes back before 1450, but really erupted in 1465. Until Henry's death in 1472, Rivo defended the position of Peter Auriol on the subject of divine foreknowledge of future contingents, maintaining that propositions about the contingent future are neither true nor false, but neutral. Henry countered by accusing Rivo of heresy. The long dispute involved the
Faculties of Arts and Theology at Louvain, the Faculties of Theology at Paris and Cologne, the bishop of Tournai, the duke of Burgundy, the Greek Cardinal Bessarion, and Pope Paul II. A number of treatises were composed in the quarrel by Rivo, Henry, and several members of Bessarion circle. One of the latter group, the Franciscan Francesco della Rovere, was elected Pope Sixtus IV in 1471 and in 1474 officially condemned Rivo's doctrine, and by extension Auriol's.

The long life of Peter de Rivo, alias Pieter van der Beken, was intertwined with the development of the University of Louvain. Founded in 1425, the university quickly became one of the most vibrant in Europe. Rivo had a long career in teaching and administration and was personally involved in two controversies that raged in the university's early history: the first is the so-called Quarrel over future contingents; the second dealt with the dating of Easter. Born in the early 1420s in Aalst, a city of the County of Flanders belonging to the diocese of Cambrai, Rivo enrolled in the university in 1437 , became arts master in 1442 , and was named professor of philosophy at the College of the Castle in 1443. Already a canon in the cathedral of Saint Rumbold in Mechelen (from 1442), in 1460 he received the canonry in the collegiate church of Saint Peter in Louvain that provided the salary for the chair of rhetoric, which he held until 1470. Rivo started his studies 
in theology right after obtaining the title of master of arts. He lectured on the Sentences in 1448-1449, but after that date his theological career appears to have slowed down, since he remained for decades a simple baccalaureus formatus and was not made doctor until 1477. He next became ordinary professor, obtaining the chair of theology connected to the plebany of Saint Peter, which had belonged to his old teacher Johannes Varenacker (d. 1475). Besides his teaching activity, Rivo served as the official letter writer of the university in 1456 and was appointed rector three times, in 1457, 1477, and 1478. He was also involved in the social and political life of Louvain. During the series of riots that shook the Burgundian Low Countries after the death of Charles the Bold (5 January 1477), the succession of Mary of Burgundy, and her marriage with the Archduke Maximilian of Habsburg, Rivo was among those city notables who tried to temper the urban revolt in Louvain, mediating first between the internal factions, and then between the city and Maximilian. In August 1477, as rector and renowned rhetorician, Rivo was also in charge of pronouncing the official speech for the first entry of the archduke into Louvain. The text of this panegyric, the Relatio seu propositio coram Maximiliano Lovanii reserata in primo introitu terrarum sponse sue, is preserved in two manuscript copies dating to the fifteenth and seventeenth century (Glasgow, University Library, Sp Coll Hunterian Bf.3.15, handwritten on the blank verso of $k 8$ and continuing onto the recto and verso of an inserted vellum leaf; Brussels, KBR, MS. 17320-17330). He died on 26 January 1499.

As a professor at the College of the Castle, Rivo lectured on some of the texts in logic and natural philosophy that constituted the basis of education in arts at that time. His lectures survive in written form in four manuscripts: Greifswald, Bibliothek des Geistlichen Ministeriums, 34.D. IX; Berlin, Staatsbibliothek - Preußischer Kulturbesitz, Magdeburg 201, 220, and 227. These manuscripts were copied and read in Dominican convents of the province of Saxony between the 1460s and the 1480s and contain Rivo's commentaries on Porphyry's Isagoge (one copy), along with Aristotle's Categories (one copy), On Interpretation (one copy), Prior Analytics (one copy), Posterior Analytics (two copies), Topics (two copies), Physics (three copies), On the Heavens (two copies), On Generation and Corruption (one copy), Meteorology (two copies), On the Soul (three copies), and On Sense and the Sensible (two copies). A copy of his now lost commentary on the Metaphysics was preserved, together with an extra copy of all his commentaries on the Organon, in a codex in the Magdeburg Dom Gymnasium (MS. 165) until its destruction in World War II. Rivo also composed a philosophical treatise on the will that can be found in only one partial witness, copied and annotated in the margins by Adrian of Utrecht (later Pope Adrian VI), who studied at the Faculty of Arts of Louvain beginning in 1476 (Louvain, Maurits Sabbe Library [GBIB], Cod. 17). Most of these texts are still unedited; provisional editions of a number of Rivo's commentaries are available online. From a first general survey and selected case studies, Rivo seems to have pursued the path of the via antiqua, abiding by the directives prescribed by the early statutes of the Louvain Faculty of Arts, which forbade the teaching of John Buridan, Marsilius of Inghen, and William of Ockham, and listed instead Albert the Great, Thomas Aquinas, Giles of Rome, and Averroes as "truthful commentators" of Aristotle. In particular, Rivo seems to have shown a preference for Albert, although this tendency is not a slavish or explicit dependence.

Rivo is best known for his role in the quarrel over future contingents at Louvain. Ironically, until recently he was more famous in this regard than the scholastic whose theory he resurrected: the Franciscan Peter Auriol (d. 1322). Peter de Rivo entitled his collective works on the subject A Defense of the Doctrine of Lord Peter Auriol in the Matter of Future Contingents. In late 1446, the arts faculty asked him and the dean to investigate the suspect doctrines of a group of arts masters led by Henry of Zomeren (c. 1417-1482). With the approval of the Faculty of Theology, in mid-1447 the Arts Faculty published a statute proscribing 11 propositions, including that "determinately one part of a contradiction in future contingents is true and the other false, just as in present and past 
contingents" - in fact, this and two of the others "must be totally suppressed." Prima facie the poorly worded statute supports Peter Auriol's opinion. Among authors whose works are preserved, however, Auriol's stance had been almost universally attacked in the 130 years since its first expression. For his part, Henry of Zomeren claimed that the propositions censured were based on the teachings of Scotus.

Henry was in Paris for much of the 1450s, becoming master of theology there in 1462 . Back in Louvain he was given the prestigious chair of theology that Heymeric of Camp had left vacant at his death, so Henry could now set things right. In a quodlibetal disputation in the Arts Faculty in Advent, 1465, Rivo defended Auriol's doctrine. The debate continued the following year at the same venue. After a hiatus, in November 1469, Henry spoke out against what he considered the heretical position that Rivo had defended. When the Advent quodlibetal session opened, Rivo resumed the debate on 18 December. Henry responded 2 days later, again calling Rivo's opinion heresy. The next day Rivo replied and the Arts Faculty asked the university to force Henry to abide by the statute of 1447. Despite the university's repeated efforts to silence both sides, the quarrel escalated, coming even to physical violence among the supporters. Both Rivo and Henry composed treatises, several in the case of Rivo who, as professor of rhetoric, used his skills to the fullest extent to gain supporters that he would otherwise probably not have had. To this day, six manuscripts preserving the texts that Rivo composed for the quarrel are known to survive: four in the $\mathrm{BnF}$ in Paris (Lat. 3169, 4152, 12390 and Nouv. Acquis. 1179), one in the Vatican Library (Vat. lat. 4865), and one in the University Library of Basel (A VI 12).

Rivo adopted Auriol's defense of Aristotle's "demonstration" in chapter 9 of De interpretatione that propositions about future contingents are neither true nor false, but neutral. Furthermore, for Auriol and Rivo, not even God's knowledge makes such propositions true or false, because divine knowledge of what is future to us does not precede the future's coming about, otherwise everything would happen necessarily. Following Auriol, Rivo claimed that God's atemporal knowledge of future contingents cannot be expressed properly by any proposition, so denying truth to future contingent propositions does not affect His knowledge.

Rivo's main innovation is his articulation of various ways to take "truth." If we tell the editor on 14 July 2017, "We will submit this on 14 February 2018," this proposition is true, but only in the "popular" sense that the editor knows we are trustworthy and we intend to follow up. In the Aristotelian sense, however, by the "rigor of logic" and with truth "inhering" in it, our proposition is not true. We may have our entry ready and intend to submit, and then be punished with sudden administrative tasks. Rivo's example is this: if Plato, whom Aristotle trusts, says to Aristotle, "I will have lunch with you tomorrow," Aristotle will believe it faithfully, and say that it is true, but he will not maintain that the truth inheres in Plato's assertion. The main problem with this is prophecy. Here Rivo agrees with Auriol that prophetic propositions signify divine knowledge by the "intention" of the prophets. In Rivo's terminology, although they are not true in Aristotle's sense, by the rigor of logic and with the truth inhering in them, they are nevertheless true by the "Uncreated Truth" that the prophet makes them signify. And if we can believe Plato's promise about lunch, then we can believe God's prophecies so much more, without maintaining that truth actually inheres in them.

For Rivo, when a proposition about the future is strictly speaking true, this truth is "unimpedible." It simply cannot be true now in the Aristotelian sense that "We will submit this on 14 February" and yet still be possible for us not to submit. This also applies to prophetic and other propositions that express God's foreknowledge: "If true propositions about future contingents are required to express divine foreknowledge, one asks of my adversary, by what truth must they be true, unimpedible truth or impedible truth? If by unimpedible truth, it follows that all futures will come about unimpedibly. If by impedible truth, it follows first that God's foreknowledge can be maintained along with the said opinion of 
Aristotle, by which he only denies unimpedible truth in propositions about future contingents."

Rivo also rejects, with some ridicule, the traditional logical devices used to reconcile divine foreknowledge and the contingency of the future. The common solution to the problem of the consequence "God foreknows that we will submit, therefore we will submit necessarily" is to appeal to the composite and divided senses of the proposition, and the distinction between absolute and conditional necessity. Rivo remarks, in a way that Auriol had and Martin Luther would later: "I have been astonished at some people who explored the greatest causes with the utmost subtlety, so that they scarcely left a particle undiscussed, and yet they are satisfied with these solutions."

Lacking the university's support, Henry denounced Rivo and his cohort to Pope Paul II and called on his allies for assistance: the duke of Burgundy, his alma mater the Faculty of Theology at Paris, and the powerful Greek Cardinal Bessarion in Rome. Rivo counterattacked, accusing Henry of the determinist heresy of Wyclif, and the university appealed to the Faculty of Theology of Cologne. Pope Paul ordered the bishop of Tournai to investigate, while Bessarion held a philosophical inquiry, soliciting tracts from Fernando de Cordoba, Guillaume Baudin, the Dominican Giovanni Gatti, and the Franciscans Giorgio Benigno Salviati and Francesco della Rovere, the latter about to be elected Pope Sixtus IV in August 1471. Rivo wrote a commentary on della Rovere's treatise and refutations of Baudin's and Henry's own works. In the end, Sixtus held an inquiry and, after Henry of Zomeren's and Bessarion's deaths in 1472, Rivo was forced to retract his position in 1473 . When he tried to interpret his retraction in a benign manner, he was investigated for backsliding. New light on this final phase of the quarrel is shed by a series of texts contained in MS. Leuven, Universiteitsbibliotheek, 1635, composed between 1473 and 1476 in opposition to Rivo's doctrines by an anonymous Thomist theologian active in Louvain at the time. Meanwhile, in 1474, Pope Sixtus IV published the bull Ad Christi vicari formally condemning the opinion of Peter de Rivo and, therefore, Peter Auriol.
Rivo signed a new retraction in 1476 and he was allowed to resume his activities in 1477, when he was finally promoted to doctor and professor of theology. In his last will and testament, however, he seemed to have professed again his old belief, stipulating that his beneficiaries "should conform in their teaching to the statute drawn up by the Faculty of Theology at the request of the Faculty of Arts," that is, the same statute that during the quarrel he advocated as defending his own position in the matter of future contingents.

The memory of the quarrel and of Rivo's "heresy" lingered among the historiographers of Brabant from the end of the fifteenth to the twentieth century. Petrus Impens (d. 1523), prior of Bethlehem in Herent, recorded a short report on the events in his Chronicon Bethlemiticum. Texts related to the debate, including some preserved in MS. Leuven 1635, were still circulating in Louvain at the beginning of the seventeenth century, as witnessed by the Jesuit Cardinal Juan de Lugo (1583-1660), who discussed them in his Disputationes de mysterio incarnationis (1633). One century later, they were also mentioned in Martin Ortiz's Caduceus theologicus et crisis pacifica de examine thomistico in tres partes divisa (1733). The editing of the corpus of treatises and documents connected to the quarrel began with the works of the Louvain historian Valerius Andreas (1588-1655) and of the theologian Charles du Plessis d'Argentré (1637-1740), and it is still in progress.

Despite the papal condemnation for heresy, Peter de Rivo spent the last 25 years of his life as a well-respected theologian and member of the city élite. Among the texts that he wrote at this stage, works related to chronology take pride of place. Rivo had an interest in matters concerning the dating of Christ's life and the calendar at least since 1449. In 1471 he composed the Dialogus de temporibus Christi, which imagines a discussion between a Jew, Gamaliel, and a Christian, Paul, concerning the conflicting theories on the day and hour of the birth and the passion of Christ, by examining issues such as historical and computistical methods and a proposal for the reform of the calendar (New York, Columbia University, Rare Book \& Manuscript Library, 
Western MS. 31). Later in his life, Rivo specifically dedicated a short treatise to calendar reform, the Reformatio kalendarii; this text was considered lost until it was discovered bound in an incunabulum of the Cambridge University Library (Inc 3.F.2.9 [3294]).

Another example of his interest in establishing chronologies is the Monotesseron, a harmony of the Gospels echoing in the title the more famous work by Jean Gerson. Its purpose was to provide a coherent account of the life of Christ, putting in order the texts of the four Gospels and trying to resolve their discrepancies. Through this work, the reader would then be able to get an overview of the events in their correct historical order and to memorize their sequence using the system of rubrics, tables, and mnemonic verses that accompanied the text of the Vulgate. In the prefatory dialogue Rivo explains the criteria he followed for establishing the order among the four narrations (he takes Luke as the leading evangelist) and describes this complex system of paratexts. The Monotesseron is transmitted in two versions: a synopsis, authored by Rivo and partly accompanied by a commentary, and a unified harmony, which is probably an anonymous reworking. It is preserved in five manuscripts, in which the layout of Rivo's work is differently reshaped according to the needs of his readership - in particular, those of the Brabantine priories of Augustinian canons affiliated with the Congregation of Windesheim, where the liturgical calendar was central to devotional life (MSS. Brussels, KBR, 129-130, 5570, 11750-11751; Paris, Bibliothèque Mazarine, $300 / 1$; and Wien, Österreichische Nationalbibliothek, Cod. Ser. n. 12890).

Rivo's most famous contributions in this domain, however, are the computistical works he wrote against Paul of Middleburg (1445-1533), former student of theology and medicine in Louvain, then doctor of medicine and professor of astrology at the University of Padua, as well as personal astrologer and physician of the dukes of Urbino. The occasion was a dispute on the dating of Easter, initiated by Paul in 1487, when he proposed in an Epistola addressed to the University of Louvain that the traditional opinion according to which Jesus died on Friday
25 March and was resurrected on the following Sunday failed to harmonize the events described in the Gospels with the astronomical calculations. According to Paul's estimate, Christ died instead on Monday 22 March and was resurrected on the following Thursday. Peter de Rivo reacted in defense of the traditional dating by publishing in 1487 the Opus responsivum ad epistolam apologeticam Magistri Pauli de Middelburgo de anno, die et feria dominicae passionis, followed, 4 years later, by the Tertius tractatus de anno, die et feria dominicae passionis atque resurrectionis, probably in response to other letters addressed to him by Paul of Middelburg. The controversy probably went cold shortly after 1492 .

Among the writings by Rivo that have come down to us, one should finally mention three short texts: a dialogue in verses, an example of biblical exegesis, and a case of pastoral theology. The first was published in Leiden in 1509 with the title Libellus quo modo omnia in meliorem partem sunt interpretanda and consists of a dialogue between Man and Reason about how the dramatic events of the history of salvation should be considered as a path to the greater good. The second is a brief explanation of Ambrose of Milan's commentary on Ps. 118:154 "Judge my judgment and redeem me: quicken thou me for thy word's sake" (Explanatio verborum Ambrosii in versiculo secundo vicesimi octonarii psalmi CXVIII), presented as an appendix to Ambrose's text in a manuscript in the Bibliothèque Mazarine in Paris (MS. 567). The last is a letter to an anonymous friend, frater professus of the priory of Augustinian canons of Groenendaal, in which Rivo addresses three doubts in matters of confession; the text is followed by Rivo's epitaph (Stuttgart, Württembergische Landesbibliothek, Cod. HB I 10).

\section{Cross-References}
Basil Bessarion
- Future Contingents
Heymeric of Camp
$\checkmark$ John Gerson
> John Wyclif 
- Modal Theories and Modal Logic

$\checkmark$ Peter Auriol

- Universities and Philosophy

\section{Bibliography}

\section{Primary Sources}

Baudry, L. (Ed.). (1950). La querelle des futurs contingents (Louvain 1465-1475). Paris: Vrin.

Champion, M. S., Masolini, S., \& Nothaft, C. P. E. (forthcoming 2019). Peter de Rivo: On chronology and the calendar. Leuven: Leuven University Press.

de Rivo, P. (1488). Opus responsivum ad epistolam apologeticam Magistri Pauli de Middelburgo de anno, die et feria dominicae passionis. Louvain: Ludovicus Ravescot. [USTC nr. 438744] (repr. in 1492, although no surviving copy of this edition has been found so far).

de Rivo, P. (1492). Tertius tractatus de anno, die et feria dominicae passionis atque resurrectionis. Louvain: Ioannes de Westphalia. [USTC nr. 438745].

de Rivo, P. (1509). Libellus quomodo omnia in meliorem partem sunt interpretanda. Leiden: Jan Seversz. [USTC nr. 420220].

de Rivo, P. (forthcoming 2019). In S. Masolini \& C. Schabel (Eds.), Defensio doctrine domini Petri Aureoli in materia de futuris contingentibus. Leuven: Leuven University Press.

Fredericq, P. (1905). L'hérésie à Louvain vers 1470. Bulletin de la classe des Lettres et de la classe des BeauxArts, 66, 11-77.

Georgius Benignus Salviati OFM. (1997). De arcanis Dei. In G. J Etzkorn (Ed.), Cardinal Bessarion, De arcanis $\mathrm{Dei}$, with introduction by S.F. Brown. Rome: Miscellanea Francescana.

Guerlac, R. (trans) Baudry, L. (1989). The quarrel over future contingents. (Louvain, 1465-1475). Paris: Vrin.

Laminne, J. (1906). La controverse sur les futurs contingents à l'Université de Louvain au XVe Siècle. Bulletin de la classe des Lettres et de la classe des Beaux-Arts, 67,372 .

Masolini, S. (2016). Petrus de Rivo (ca. 1420-1499): Portrait(s) of a Louvain Master. PhD Dissertation, KU Leuven (provisional editions of Rivo's Epistola to the friar of Groenendaal, the Relatio seu propositio coram Maximiliano Lovanii reserata in primo introitu terrarum sponse sue, and De Petri negationibus).

Masolini, S., \& Schabel, C. (forthcoming 2019). The end of the quarrel over future contingents at Louvain: New texts from Leuven, Universiteitsbibliotheek ms. 1635. Leuven: Leuven University Press.

Schabel, C. (1995-1996). Peter de Rivo and the quarrel over future contingents at Louvain: New evidence and new perspectives. Documenti e Studi sulla tradizione filosofica medievale, (Part I) 6, 363-473, and (Part II) 7, 369-435.
Tournoy, G. (1977). Een onbekende autograaf van Petrus de Rivo (Leuven, ca. 1470). In V. E. EJM et al. (Eds.), Facultas S. Theologiae Lovaniensis 1432-1797: Bijdragen tot haar geschiedenis (pp. 293-297). Leuven: Leuven University Press.

https://hiw.kuleuven.be/dwmc/peterderivo.

\section{Secondary Sources}

Bartocci, B., \& Masolini, S. (2014). Reading Aristotle at the University of Louvain in the fifteenth century: A first survey of Petrus de Rivo's commentaries on Aristotle (II). Bulletin de Philosophie Médiévale, 56, 281-383.

Bartocci, B., Masolini, S., \& Friedman, R. (2013). Reading Aristotle at the University of Louvain in the fifteenth century: A first survey of Petrus de Rivo's commentaries on Aristotle (I). Bulletin de Philosophie Médiévale, 55, 133-176.

Bianchi, L. (2008). Pour une histoire de la "double vérité". Paris: Vrin.

Champion, M. S. (2017). The fullness of time: Temporalities of the fifteenth-century low countries. Chicago: University of Chicago Press.

Evans, J. R. (2001). The Boethian solution to the problem of future contingents and its unorthodox rivals. $\mathrm{PhD}$ Dissertation, University of Nebraska.

Gabriel, A. L. (1974). Via antiqua and Via moderna and the migration of Paris students and masters to the German universities in the fifteenth century. In A. Zimmermann (Ed.), Antiqui und Moderni: Traditionsbewusstsein und Fortschrittsbewusstsein im späten Mittelalter (pp. 439-483). Berlin: de Gruyter.

Gabriel, A. L. (1978). Intellectual relations between the University of Louvain and the University of Paris in the 15 th century. In J. Ijsewijn \& J. Paquet (Eds.), The universities in the late middle ages (pp. 29-41). Louvain: Leuven University Press.

Geudens, C., \& Masolini, S. (2016). Teaching Aristotle at the Louvain Faculty of Arts, 1425-1500: General regulations and handwritten testimonies. Rivista di Filosofia Neo-Scolastica, 108(4), 813-844.

Kałuża, Z. (1995). La crise de années 1474-1482: l'interdiction du nominalism par Louis XI. In M. J. F. M. Hoenen, J. H. J. Schneider, \& G. Wieland (Eds.), Philosophy and learning. Universities in the middle ages (pp. 293-237). Leiden/New York/Köln: Brill.

Macken, R. (1997). Medieval philosophers of the former low countries. Bio-bibliography and catalogue. Leuven: Leo Belgicus.

Nothaft, C. P. E. (2012). Dating the passion. The life of Jesus and the emergence of scientific chronology (200-1600). Leiden: Brill.

Nothaft, C. P. E. (2018). Scandalous error: Calendar reform and calendrical astronomy in medieval Europe. Oxford: Oxford University Press.

Schabel, C. (2000). Theology at Paris, 1316-1345: Peter Auriol and the problem of divine foreknowledge and future contingents. Aldershot: Ashgate. 
Van den Broecke, S. (2003). The limits of influence: Pico, Louvain, and the crisis of renaissance astrology. Leiden: Brill.

Weiler, A. G. (1978). Les relations entre l'université de Louvain et l'université de Cologne au $\mathrm{XV}^{\mathrm{e}}$ siècle. In
J. Ijsewijn \& J. Paquet (Eds.), The universities in the late middle ages (pp. 49-81). Louvain: Leuven University Press. 